\title{
29
}

\section{Migrant and Ethnic Politics in the 2016 Election}

\author{
James Jupp and Juliet Pietsch
}

The outstanding feature of the 2016 federal election was that immigration, refugees, ethnic integration and multiculturalism were scarcely mentioned by the major parties, but they were focused on mainly by the Greens and a hostile Pauline Hanson's One Nation (PHON). The epic separation of the United Kingdom (UK) from the European Union (EU), which ran almost parallel to the Australian campaign, centred on resentment about the EU basic policy of free movement of goods and migrants. Moreover, continuing warfare and terrorism in the Middle East kept Islam in the forefront of public discussion as a major threat. Australia retreated into the safety of traditional suburban issues: jobs, incomes, health and education. Many of the debated issues were within the province of State governments rather than the Commonwealth. The cross-country high-speed train debate emerged again from darkness. The elections in Queensland (QLD) and Tasmania (TAS) were especially parochial, but not unique. The Labor leader Bill Shorten leaped ahead with the threat to Medicare. The Coalition simply repeated the old tale of the budgetary mess that Labor had left behind such as the asylum seeker deaths by drowning they had caused. PHON, marginal Liberals and odd Independents kept up an uninformed barrage against Muslims, which had a very limited reaction from the party leaders (Chan 2016). 
Few candidates seemed anxious about Islam, terrorism, the EU, apportioning blame for the original Iraq war, the shift of immigration towards India and China, the Chinese military presence in the South China Sea, or even the highly eccentric international role of US presidential candidate Donald Trump. This retreat from the 'real world' included virtually ignoring the growing public concern about the asylum seekers locked up in Pacific Islands for no crime other than coming to Australia by an unofficial route (Australian Human Rights Commission 2014; Amnesty International/Human Rights Watch 2016). Demonstrations on this and other international or ethnic issues were well attended, but had no visible impact on the mainstream political struggle. After the election, international heat became stronger. Only with the terrorist attack in Nice and the coup in Istanbul in July was there much Australian interest displayed in anything international, other than commemoration of longforgotten battles of World War I. A major survey suggests a declining public confidence in government, but still a reasonable level of public support (Markus 2016).

Despite this apparent indifference to the outside world, that world was moving in dangerous and reactionary directions. In Europe, parties of the 'Right' were recording increased majorities on issues like immigration, Islam, national identity, the flood of refugees from Iraq and Syria. There was a decay of many liberal and socialist parties in the face of nationalism and racism, some of which did not hide a fascist inheritance. The Australian response was largely confined to a segment of the Liberal Party favourable to the former prime minister, Tony Abbott, and encouraged by the Murdoch press, especially the Australian. Its counterparts in Britain were also encouraged by the Murdoch Sun, and encouraged by the United Kingdom Independence Party (UKIP). UKIP was the real victor of the British election of 2015, establishing strong votes in former Labour districts, which, in 2016, voted to leave the EU. Australia had nothing comparable, despite the creation of a 'conservative' strand that was threatening to move outside the Liberal-National Coalition. All this international agitation passed by the major parties, with their leaders firmly fixed on domestic issues. To many Australians with international origins or heritage, the election might have seemed like a battle by 'Anglo' Australian politicians on parochial 'Anglo' issues. 


\section{The decline of migrant and ethnic politics}

Despite this marked retreat from the 'real world', issues underpinning multiculturalism and political inclusion remained significant. There was active campaigning among migrants and ethnic minorities and general concern with Islam, terrorists, Indigenous inequality, immigration levels and social cohesion. Detailed analysis of the possible impact of such issues was complex, confined to a relative handful of academics and involved organisations like the Refugee Council of Australia (RCA) or the Federation of Ethnic Community Councils of Australia (FECCA). Candidates from the major parties pronounced Australia as the 'most successful multicultural country in the world' without making any comparative references to anywhere else. Yet, in practice, at the Commonwealth level, nearly all multicultural institutions have been abolished. These institutions were initially established in an effort to build a nondiscriminatory policy framework for migrants and ethnic minorities from non-English speaking backgrounds (NESB). The overall aim of multiculturalism was to dismantle the remaining remnants of the White Australia Policy and provide the foundations for the future social and political integration of migrants from NESB. Some of the significant policies and programs of multiculturalism included improvements in the Adult Migrant Education Programme, which was initiated in 1947 to teach survival English to refugees; free telephone interpreter services for migrants from NESB and emergency services; the establishment of Migrant Resource Centres and the introduction of a Special Broadcasting Service (SBS).

The results of the 2016 federal election suggest that the dismantling of multicultural policies and programs was shortsighted and has had consequences for the quality of representative democracy in Australia. In terms of descriptive representation, Australia's Commonwealth Parliament is one of the most unrepresentative in the western world (Karina 2006). For example, despite a long history of non-European migration, which is now on a par with the rate of European migration, few migrants or ethnic minorities with Asian, African or Pacific Islander ancestry were elected to the House of Representatives in the 2016 federal election. Only four representatives with Asian ancestry were elected to the House of Representatives and the Senate. Yet, in 2016, nearly 12 per cent of Australia's population identified as having Asian ancestry. This suggests that the long-term goal of political equality for all Australians, regardless 
of cultural, religious or linguistic background recommended in the Don't Settle for Less report (Immigration and Ethnic Affairs 1986) is yet to be realised (Zappala 2001). Without a strong multicultural legislative and policy framework, the Australian political landscape has fallen a long way behind other Commonwealth countries with shared migration histories such as Canada and New Zealand.

Leading up to the 2016 election, FECCA asked whether the major parties were prepared to develop a national legislative framework on multiculturalism. In brushing aside the significant cutbacks the Coalition made to multicultural policies and programs, the government stated that 'no legislation is required to further enhance support of our multicultural communities' (FECCA 2016). The Labor Party similarly watered down any long-term commitment to multiculturalism by stating that it will continue to combat racism and re-establish the Office of Multicultural Affairs within the Department of Social Services, invest in the AMEP and support new courses in workforce participation (FECCA 2016). Such promises fail to acknowledge the overriding national importance of cultural diversity within Australia’s representative institutions.

Over the past few decades, there has been a significant shift in the makeup of Australia's migration program, which has reoriented its yearly intake towards Asia (Salt 2016). In the future, new migrant communities will grow to become significant political blocs to which parties will need to pay close attention (Jakubowicz 2016). Within such an environment it may be timely to revisit the possibility of an Australian Multiculturalism Act that builds on progress being made at the State level. For instance, New South Wales (NSW), Victoria (VIC) and South Australia (SA) have specific multicultural legislation in place. Western Australia (WA) enacted a Multicultural and Ethnic Affairs Commission Act in 1983, but this was repealed in 2006. In 2016, the Queensland (QLD) parliament passed the Multicultural Recognition Act (see also Ozdowski 2015).

The issues of immigration, multiculturalism and cultural diversity have largely been replaced in Australian federal election campaigns with an almost obsessive focus on the issue of asylum seekers and boat people (Glynn 2016). The Coalition enlarged upon its success in stopping the boats and the foolishness of Labor in opening the flood gates to asylum seekers when in office. Essentially, there was no real difference between the two major parties on this issue, with only the Greens campaigning against the detention of entrants without a visa. As in other multicultural societies, 
such as Britain or the United States, canvassers and propagandists sought to appeal to the ethnic vote by such ancient traditions as advertising in ethnic newspapers or sending a representative along to relevant meetings. Polling organisations had great difficulty in defining and predicting the likely loyalties of ethnic targets. The assumption remained that ethnic minorities (including the Indigenous peoples) were more likely to prefer Labor to the Coalition. Why this might be so, when there was little policy difference between the major parties, was never made clear. Some polling suggested only that many 'ethnic' Australians were just as unsympathetic as the 'Anglo' majority to asylum seekers who were perceived to be jumping the gun, especially when that affected family reunion for their own group. Conservative candidates made use of this resentment in relevant electorates, but with little visible impact. The only electorates with a large 'ethnic' presence that shifted from Liberal back to Labor were Barton (NSW) and Hindmarsh (SA). Green support in Batman (VIC) was concentrated in the southern booths adjoining Green Melbourne. The more 'ethnic' northern booths, with long-established Greek and Italian loyalties, remained Labor. Green sympathy with detained asylum seekers did not seem to attract a shift among these older voters.

In the final event there were few significant gains or losses in electorates with large ethnic populations, either in 2010, 2013 or 2016 (Jakubowicz 2013). However, there were continuing shifts in the origins and loyalties of that section of the population who had either been born outside Australia in a non-Anglo culture, had parents from there or used a language other than English at home (see Pietsch 2017). This was not the same as the 'migrant' population, almost a million of whom had been born in the United Kingdom and another half million in New Zealand, Canada, the United States or elsewhere in the 'Anglosphere'. This large Anglosphere migrant component of the electorate has rarely been seriously analysed (Hammerton and Thomson 2005; Pietsch 2017). It is especially influential in WA and SA and, if anything, more conservative than the average, except in the WA seats of Brand, Fremantle and Burt. In outer suburban Dunkley, with the largest population of British origins in Victoria, Liberals narrowly held the seat. Working-class 'British' districts such as Brand (WA) or Makin and Kingston (SA) retained their Labor loyalties. Essentially, the picture of Labor reliance on a block of 'ethnic' voters remained the same as for many previous years. However, the makeup of the 'ethnic' population was changing. Ageing migrant communities from Europe were being replaced by newcomers from Asia and the Middle East, many of whom were settling in middle-class districts. 


\section{Ethnic Australia: A shifting sea of change}

While a majority of voters, and a much larger proportion of politicians, were of 'Anglo'-Australian or 'British' origins, it was still necessary to understand and recruit support from non-Anglo or British origins, especially as voting has been compulsory for citizens throughout the whole period of non-British immigration. This was gradually accepted by the Liberal and Labor parties in the half-dozen major cities in which most immigrants settled. It was rarely important for rural Australia and the National Party, or for QLD, TAS and WA. Understanding ethnic and multicultural Australia requires a detailed knowledge of a very complex and diverse society. However, Australia has historically emphasised uniformity and cohesion and still does, unlike the United States, Canada, New Zealand or even the United Kingdom. British origins, language, political systems and immigration rules have traditionally all given preference to English-speaking 'Europeans'. Political leaders as varied as Henry Parkes, Dr Evatt, Bob Menzies, John Howard and Abbott have all given support to this tradition and to its implementation as public policy. When circumstances required broader immigrant sources, newcomers have been largely expected to subscribe to the national ideology of social cohesion and the sole national language of English. Those who did not come from that tradition tended to be seen as outsiders, at best, or positively dangerous at worst. While the urgency of this approach gradually waned, it was still highly significant in politics and given public voice by leaders like Howard into the present century. At the same time, partly as a reaction, partly as a needed compromise, tolerance was emphasised as a national virtue. However, 'tolerance' was regularly denied by opponents of Islam and by PHON supporters. By 2016, official multiculturalism had been relegated to the Department of Social Services, from its once lofty role in the Department of Prime Minister and Cabinet. The SBS was commercialised for food lovers, and regularly threatened with amalgamation with the $\mathrm{ABC}$.

As elsewhere, tolerance can be affected by changing circumstances. This became apparent after 1945 with the sudden and massive intake of refugees from postwar Europe with all-party agreement. Multiculturalism survived as the basic, if controversial, ideology of nation-building. By the start of the bicentennial century in 1988, this was endorsed by Labor leader Hawke and former Liberal leader Malcolm Fraser. Commonwealth and State governments designed laws and programs to create unity 
through diversity. Among these were eventually contradictory attempts to define Australians as a united and even uniform people, with common values originating in the English-speaking world, but with a variety of religions, cultures and original 'homelands'. Howard always found this hard to understand, but Fraser did not (Jupp 2007).

This state of affairs was being steadily challenged by the start of the new era in 2000. The shattering impact of rising Islamic militancy was the major element disturbing a rather self-satisfied nation. But even before the turn of the century, the 'ethnic vote' was being debated, the issue of Aboriginal inequality had been raised to the national level, nationalist parties like Australians Against Further Immigration were born and conservatives began to speak openly of the risks of multiculturalism. The road was open for Pauline Hanson's One Nation with her significant swing in 1996 against multiculturalism and Asian migration. There was very little active terrorism in Australia, but enough to turn the public away from tolerance and governments back towards emphasising the dangers of uncontrolled immigration from the Muslim world (Overington 2016).

The electoral scene set in 2016 had its roots in this anti-immigration sentiment and revived racism 10 years earlier (Leach, Stokes and Ward 2000; McAllister and Cameron 2014). Anti-immigration sentiment was strongest in QLD, but the main influences came from the United States after the 9/11 terrorist attacks, and from the Islamic world, with the failed Vietnam war being replaced by the failing war against Iraq. The ethnic groups from Eastern Europe that were created in Australia after World War II were becoming aged. These post-World War II refugees were restricted to mainly Catholic Europeans by official policy. Most were fairly conservative. Their children and grandchildren now make up a significant membership of the conservative parties. There was very little addition from immigration following the post-World War II period. Their birthplaces in 2011 included Poland $(48,613)$, Romania $(14,026)$, Russia (18,241), Serbia (20,257), Bosnia $(25,667)$, Croatia $(48,779)$, Czech Republic $(7,417)$ and Hungary 19,068 (Australian Bureau of Statistics (ABS) 2011). From this total of 202,068 people comes a population likely to have experienced communism in one form or another, and to have their consequent sympathies directed toward the Liberal Party. They might be described as the founders of multiculturalism or the 'displaced persons'. Many have shifted from inner-city industrial suburbs of Melbourne, Sydney and Adelaide to outer suburbs such as Dandenong or Sunshine. Most have produced second or third generations who may 
still identify with the parental homeland, or not, as they think fit. They differ from the following flow of Southern Europeans (Greek, Italians, Maltese) who formed a pro-Labor bloc that still survives, but is also ageing (Pietsch 2017).

\section{From Asians to Muslims and migrants to boat people}

Contrasting with this early intake of Europeans into Australian society are the growing numbers of Chinese and Indians who have arrived in recent years. The migrants are varied in culture, language and histories. They can never be meaningfully described 'as a whole', any more than can Europeans. Within Australia, their places of residence vary greatly across the major cities, as do their religious institutions, social networks and political allegiances. Chinese are divided culturally between Mandarin speakers (mainly from China and Taiwan) and Cantonese speakers (mainly from Hong Kong, Singapore, Southeast Asia and from the original Australian settlement before 1920). In Sydney, Cantonese speakers may be found mainly in Banks (10,452), Barton (10,587), Bennelong (12,293), Bradfield (8,376), Fowler (7,713), Parramatta $(8,555)$ and Reid $(9,798)$. Mandarin speakers number 9,940 in Banks, Barton $(11,866)$, Bennelong $(13,202)$, Kingsford Smith $(7,249)$, Parramatta $(10,324)$ and in Sydney $(8,648)$ (see Appendix). Both Cantonese and Mandarin speakers can be found in large concentrations in comfortable middle-class suburbs. Chinese from varied origins are mainly located in Sydney or Melbourne. Smaller communities can be found in the other major cities. Immigration policy, by choosing skilled and educated intakes, affected the politics of established groups and the areas in which they chose to live. Many Chinese of both major cultures now live in the Sydney north shore seats of Bennelong or Bradfield.

A rapid increase in Indian immigration in the previous decade has introduced a major change among those who might be termed 'ethnic'. While many give English as their language of the home, increasing numbers nominated an Indian language. These are predominantly Hindi $(111,253)$, Punjabi $(71,170)$, Tamil $(50,108)$, Bengali $(35,610)$ and Gujerati $(34,197)$ in Sydney; but a different pattern is evident in Perth: Malayalam $(25,080)$ or Kanada $(5,926)$ (see Appendix). Many of the latter South Indians, like Tamils in Sydney, are Christian. A substantial 
number of Indians are students and fluent in more than one language. Indian languages such as Urdu or Tamil are widely spoken by those not of Indian birth, namely Sri Lankan, Pakistani, Bangladeshi or Nepali. Like the Chinese, many Indians have settled in the past in Malaysia and Singapore, in Nepal, Thailand or even some Pacific islands, notably Fiji. They may have acquired dual or triple loyalties, languages, religions or cultures that distinguish them from the majority category of 'Indian' or 'Chinese'. One example is the Catholic Chinese of East Timor, who have been settled as refugees in the Northern Territory (NT). These groups with mixed origins have been an important factor in the formation of ethnic organisations in Australia. Other groups have been based on religion, with there being substantial organisations for Hindus, Muslims, Eastern Orthodox or Catholic Christians, Sikhs and Buddhists. India can truly claim to be the most multicultural society on earth, and this is reflected in their Australian immigrants. Like the Chinese, many are prepared to adopt some 'western' cultures and loyalties. Both Indian and Chinese migrants have prospered in business rather than in representative politics, where European and Middle Eastern influence has been more marked, especially at the local level.

Indian-born language speakers totalled 295,016 in 2011, but many were born outside India (ABS 2016). The largest number of Tamil speakers in Sydney was in the electorates of Parramatta, Greenway and Blaxland (all Labor) and Reid (Liberal) (ABS 2011). Many Tamils were from Sri Lanka, which was in a state of conflict for over 30 years. Fewer Sinhalese and Tamils were focused on south-east Melbourne electorates, including Bruce and Hotham (Labor) and Chisholm and Deakin (Liberal), and these groups tended to be more politically active. A large but little noticed element is from the Philippines, numbering 171,015 in 2011. Like the Indians, most are fluent in English, but many also use their own languages in social and local affairs. Some Filipinos are recruited to support the major parties, most noticeably in the western Sydney city of Blacktown. These include speakers of Tagalog $(81,354)$, Filipino $(55,338)$, Cebuano $(1,422)$ and Bisaya $(2,237)$.

Arabic migration to Australia extends back to the nineteenth century, and consists mainly of Lebanese. Avoiding the White Australia Policy, the great majority were Christians, which remains true of many Lebanese today. Muslims were more likely to be Afghans or North West Frontier Indians than Arabs, and were brought to central Australia for the camel transport industry. Nominally British subjects, they were eventually relieved of some 
penalties of the White Australia Policy. Although the majority of Muslims in Australia may come from Muslim countries, categorisation obscures a wide variety of Iranians, Afghans, Somalis, Sudanese, Indonesians, Malaysians, Bosnians, Turks, Egyptians, Africans, Ethiopians and many others. Those speaking Arabic totalled 286,840 in Australia in 2011, of whom 76,379 were Lebanese. Those born in Muslim states were mainly from Pakistan (30,168), Sudan (19,292), Afghanistan (28,540), Indonesia $(103,059)$, Iran $(34,370)$, Iraq $(48,105)$ and Malaysia $(116,008)$.

\section{Ethnic constituencies and issues in 2016}

From the earliest days of postwar immigration to Australia any (non-Indigenous) distinctive group that tended to live together were described as creating a ghetto, following the US borrowing of the original Venetian name for the Jewish quarter. While this term faded as multiculturalism was developed, it had sprung to life again by 2000, being favoured by Hanson among others. In the USA, the Jewish American, and later the African American and Italian American, concentrations were usually poor, disadvantaged and considered dangerous. The only major examples of ghettoisation in colonial Australia were in Sydney around the Rocks and Surry Hills, and were predominantly Irish. Melbourne had a very small Italian concentration in Dorrit Street, Carlton, by the 1930s, but Carlton is now too expensive for newcomers to buy property in. As with Leichhardt in Sydney, Italians and their descendants socialise in these inner-city districts, but now live and vote further out in the suburbs.

By the 1950s, the term 'ghetto' was revived with the arrival of the postwar displaced persons and Italians and Greeks, and applied from time to time to Vietnamese and anyone else who preferred to settle with their own people. Australian elections are based on defined geographical areas, and these concentrations were usually apparent and attracted criticismespecially Vietnamese Cabramatta and Muslim Lakemba, both in innerwestern Sydney. Chinatowns tended to develop as eating places in both Sydney and Melbourne, and lost their nineteenth-century reputation as dangerous. Many Sydney Chinese living elsewhere use such areas for shopping and eating, rather than for voting. The same is true in Melbourne for Little Bourke Street. Similarly, the Jewish communities of north shore Sydney or Caulfield Melbourne have mostly moved away from their original bases in Bondi or Carlton. As 'ghettoisation' in Australia 
is unlike the US original, it does not usually matter whether groups are geographically concentrated or not. However, in terms of democratic politics, ethnic concentration matters a great deal. Party organisation usually has a geographical base and concentrated communities provide its votes, leadership, safe seats and funds.

Large and concentrated 'ethnic' communities of various origins are most evident in central and eastern Sydney (Blaxland, Chifley, Fowler, Grayndler, Kingsford Smith, McMahon, Parramatta, Sydney, Watson); and in northern, western and south-eastern Melbourne (Batman, Calwell, Gellibrand, Gorton, Holt, Lalor, Maribyrnong, Scullin, Wills). In most of these, Labor majorities of 30,000 or more are common. This is the true Labor heartland and the core of multicultural Australia. However, these areas of Sydney and Melbourne are not immune from change. Electorates like Banks, Melbourne Ports, Batman, Wills and Melbourne itself have not been safe from attack or even defeat (Pietsch 2017). Conversely, electorates in the outer suburbs, such as Bruce, Greenway, Jagajaga, or Macquarie, have attracted immigrants willing to change Liberal loyalties. In a few central electorates (Melbourne, Sydney), non-voting students from Asia may exaggerate the probable electoral impact.

Ethnic minorities are central to Australian politics. A vocal minority can often influence local politicians and councillors. Examples include the Eastern Christians (Armenians, Syrians, Chaldeans and Maronites). Their concentrated small communities all have useful links with Catholic or Protestant churches and influence the selection of refugees from persecution in the Middle East. Afghan Muslims, speaking Dari $(20,158)$, Pashto or versions of Persian $(34,483)$, are joined by the Hazaragispeaking victims of Afghan Islam. Burmese $(12,324)$ and Karen $(6,402)$ take a similar role for Myanmar. Most former refugee organisations are well aware of the need to cultivate politicians, regardless of party. A local MP can often influence immigration decisions, although many do not relish this task.

Small active enclaves include the Burmese in Perth and Stirling; the Armenians in Bennelong and North Sydney; Turks in Calwell, Wills and Scullin; Koreans in Bennelong, Berowra, Bradfield, Mitchell, Parramatta and Sydney; and Portuguese in Fremantle. These enclaves may not affect election results, but can be a basis for organisations favouring one or other of the major parties. There are no functioning minority parties with an ethnic base, the last being the Democratic Labour Party (DLP) that had 
a predominantly Catholic following of Irish-Australian background in VIC in the 1960s. Groups of refugee origin often establish tightly knit communities focused on their original homeland and its problems. This was generally true of postwar displaced persons. With ageing and acculturation and the collapse of communism, this cohort is not so large in numbers, but still varied in culture, politics, religion and skills. Many migrants come from states that would deeply resent discrimination against their communities, while others are protecting their governments from criticism. Australian relationships with Asian societies are greatly different from those of 50 years ago.

\section{Conclusion}

While voting is compulsory and most candidates are 'Anglo'-Australians, politics in Australia has a significant aspect that does not focus on Commonwealth issues. Family reunion, as an immigration policy/ platform, may be more important, as it is currently expensive and liable to curtailment. Cultural, religious and language maintenance may be the major concern of the variety of ethnic organisations. Race relations may be more important for newer arrivals. However, while ethnic variety has changed dramatically since 1946, the party systems and concerns have not moved so quickly and neither have political or academic understandings. At the grassroots, there is a wide variety of concerns in relation to finding influential roles in Australian politics, without necessarily accepting all the institutions, practices and traditions of a society still trying to ensure uniformity. Many of the campaigns and issues of the 2016 election did not even touch on the concerns of ethnic groups. From the 'golden days' of official multiculturalism, policies, funding and support have been steadily reduced and even abolished. Refugee and asylum policy has become harsh and restrictive. Yet at least one third of Australians have a multicultural background, which may modify pressures on new arrivals to assimilate and conform. Local politics often reflect a recognition of this, but national politics rarely do. 
29. MIGRANT AND ETHNIC POLITICS IN THE 2016 ELECTION

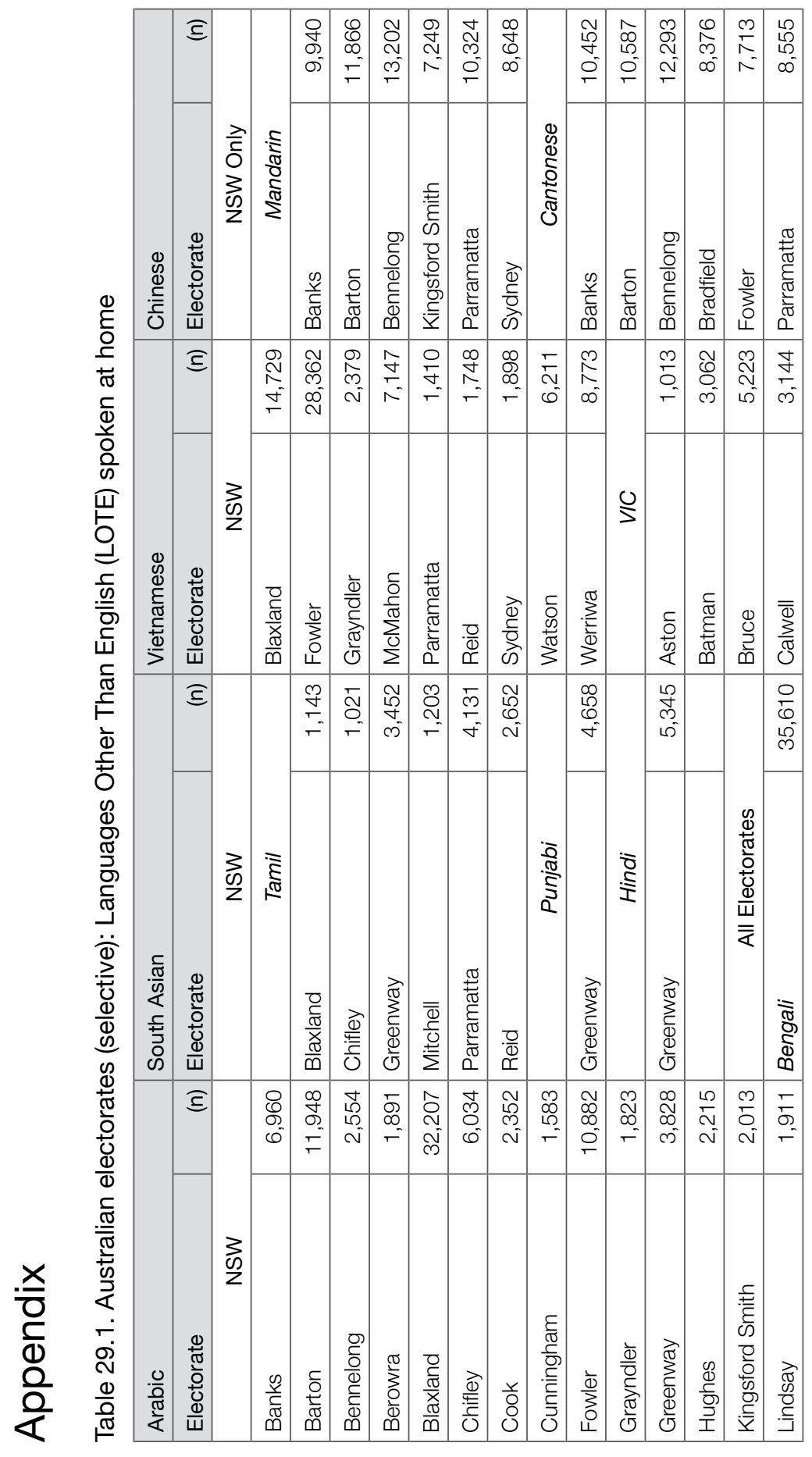


DOUBLE DISILLUSION

$\Xi\left|\begin{array}{l}\infty \\ 0 \\ N \\ \infty\end{array}\right|$

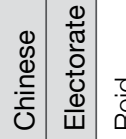

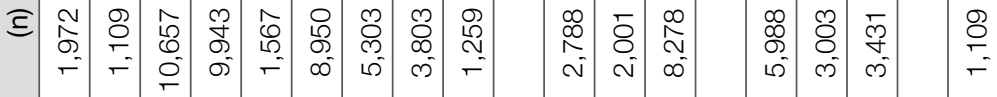

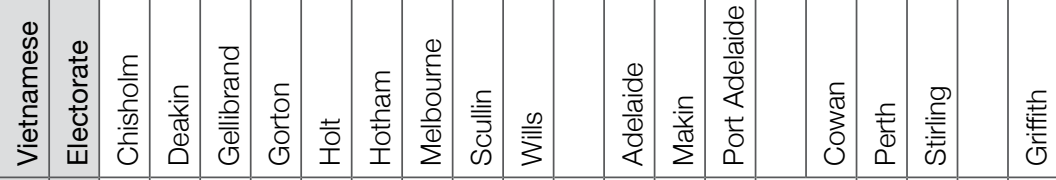

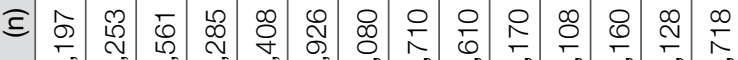

f.

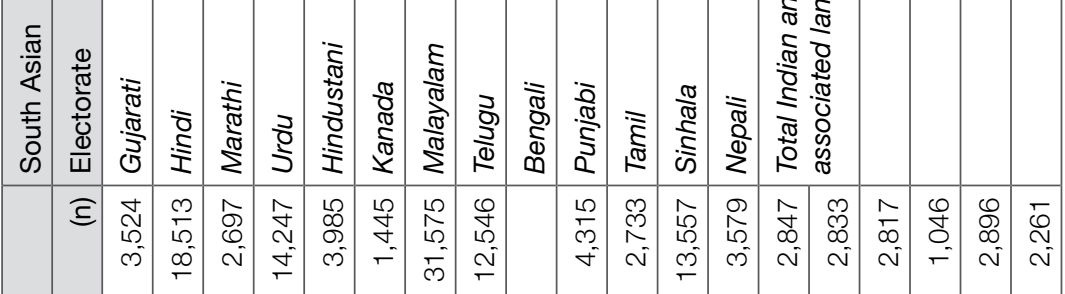

$\stackrel{0}{>}$

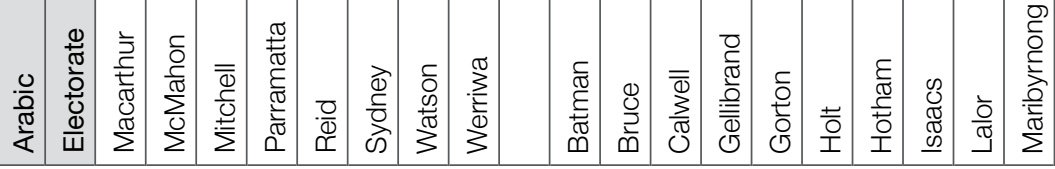


29. MIGRANT AND ETHNIC POLITICS IN THE 2016 ELECTION

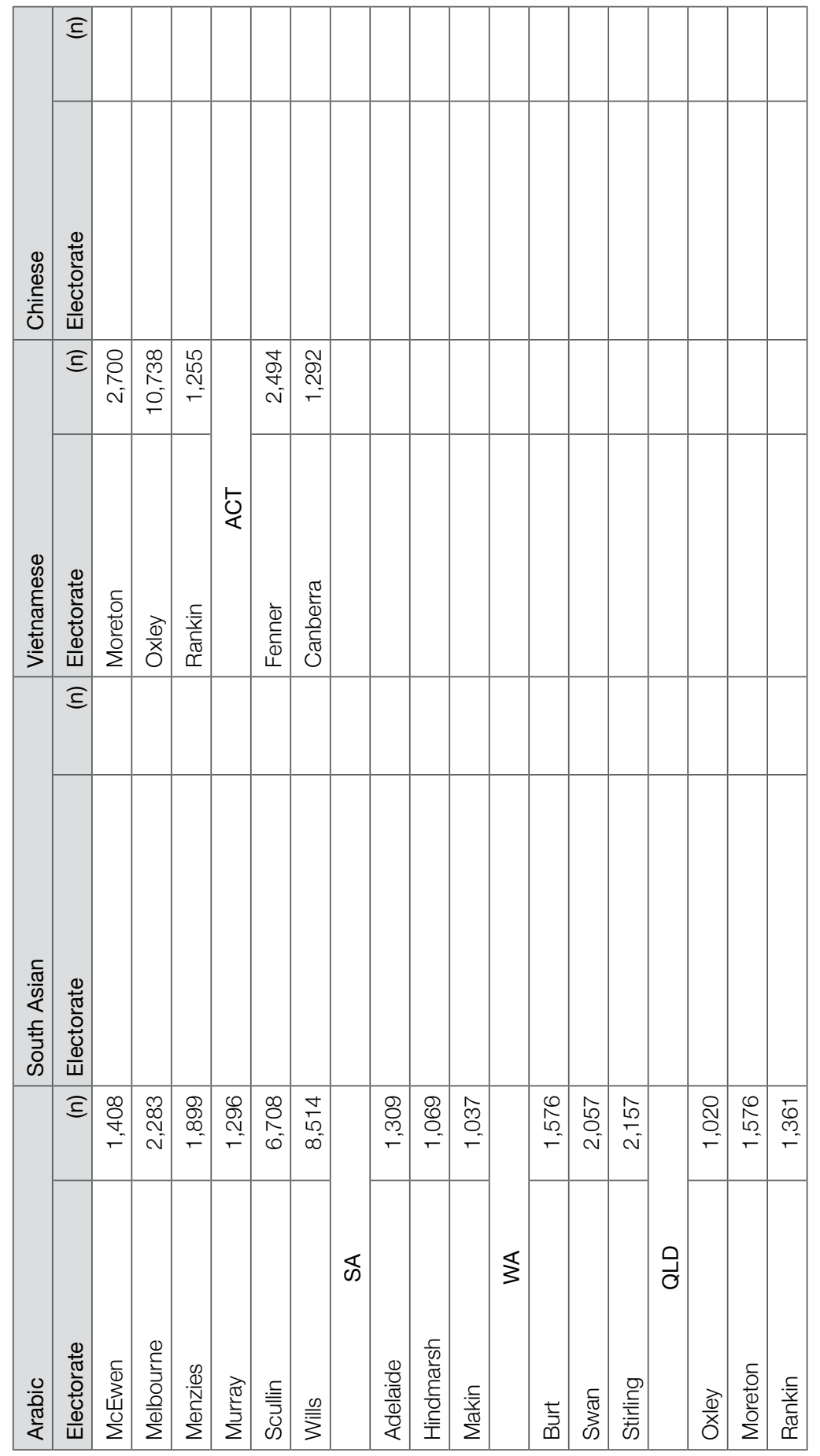


DOUBLE DISILLUSION

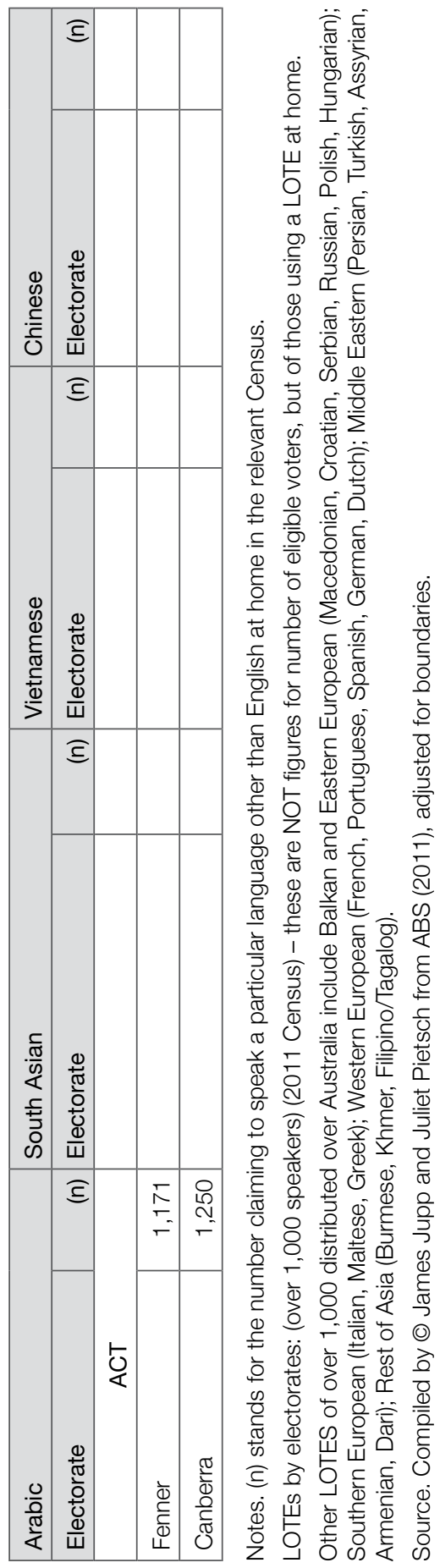




\section{References}

Amnesty International/Human Rights Watch, Australia. 2016. 'Australia: Appalling abuse, neglect of refugees on Nauru. Joint Press Release'. Human Rights Watch, 2 August. Available at: www.hrw.org/ news/2016/08/02/australia-appalling-abuse-neglect-refugees-nauru

Australian Bureau of Statistics (ABS). 2011. Census of Population and Housing. Canberra: Australian Bureau of Statistics.

——. 2016. Census of Population and Housing. Canberra: Australian Bureau of Statistics.

Australian Human Rights Commission. 2014. The Forgotten Children: A National Inquiry into Children in Immigration Detention. Sydney: Australian Human Rights Commission.

Chan, Gabrielle. 2016. 'Australia's broadly tolerant but pockets of intense prejudice remain, report shows'. Guardian, 23 August. Available at: www.theguardian.com/australia-news/2016/aug/24/australia-broadlytolerant-but-pockets-of-intense-prejudice-remain-report-shows

Federation of Ethnic Communities Councils of Australia (FECCA). 2016. Questions to Coalition, Labor and Green Parties. Canberra: FECCA.

Glynn, Iriel. 2016. Asylum Policy, Boat People and Political Discourse. London: Palgrave Macmillan. doi.org/10.1057/978-1-137-51733-3

Hammerton, James and Alistair Thomson. 2005. Ten Pound Poms: Australia's Invisible Migrants. Manchester: Manchester University Press.

Immigration and Ethnic Affairs. 1986. Don't Settle for Less: Review of Migrant and Multicultural Programs and Services. Canberra: Australian Government Publishing Service.

Jakubowicz, Andrew. 2013. 'How Labor won the "ethnic vote" in Western Sydney'. ABC News, 18 September. Available at: www.abc.net.au/ news/2013-09-13/jakubowicz-politics-of-ethnicity/4954660

__. 2016. 'Why multicultural policy looms as a Senate bargaining chip'. The Conversation, 30 July. Available at: theconversation.com/ why-multicultural-policy-looms-as-a-senate-bargaining-chip-62696 
Jupp, James. 2007. From White Australia to Woomera. Melbourne: Cambridge University Press. doi.org/10.1017/CBO9780511720222

- 2012. 'Immigration issues in the 2010 federal election'. In Marian Simms and John Wanna (eds), Julia 2010: The Caretaker Election. Canberra: ANU E Press, pp. 267-77. Available at: press-files.anu.edu. au/downloads/press/p169031/pdf/ch22.pdf

- 2015. 'Ethnic voting and asylum issues'. In Carol Johnson and John Wanna with Hsu-Ann Lee (eds), Abbott's Gambit: The 2013 Australian Federal Election. Canberra: ANU Press, 323-39. doi.org/10.22459/ AG.01.2015.19

Karina, Anthony. 2006. 'The political representation of ethnic and racial minorities'. Sydney, NSE Parliamentary Research Service: Briefing Paper 3/06, March.

Leach, Michael, Geoff Stokes and Ian Ward (eds). 2000. The Rise and Fall of One Nation. St Lucia: University of Queensland Press.

Markus, Andrew (ed.). 2016. Australians Today: Scanlon Foundation Survey. Melbourne: Monash University.

McAllister, Ian and Sarah Cameron. 2014. 'Trends in Australian Political Opinion: Results from the Australian Election Study 19872013'. Canberra: School of Politics and International Relations, The Australian National University.

Overington, Caroline. 2016. 'Muslim migration: The big slowdown'. Australian, 29 July, p. 13.

Ozdowski, Sev. 2015. 'Legislating multiculturalism: A case for a national multicultural act?' FECCA National Conference. Sydney, 5 November.

Pietsch, Juliet. 2017. 'Trends in migrant and ethnic minority voting in Australia: Findings from the Australian election study'. Ethnic and Racial Studies 40(14): 2463-480.

Refugee Council of Australia (RCA). 2016. 'Election 2016: What the parties say about refugee policy'. June. Available at: www.refugee council.org.au/publications/election-2016-parties-say-refugee-policy/

Salt, Bernard. 2016. 'Multicultural face is changing'. Australian, 4 August, p. 28. 
29. MIGRANT AND ETHNIC POLITICS IN THE 2016 ELECTION

Zappala, Gianni. 2001. 'The political representation of ethnic minorities: moving beyond the "mirror"'. In Marian Sawer and Gianni Zappala (eds), Speaking for the People. Melbourne: Melbourne University Press, pp. 134-61. 
This text is taken from Double Disillusion: The 2016 Australian Federal Election, edited by Anika Gauja, Peter Chen, Jennifer Curtin and Juliet Pietsch, published 2018 by ANU Press, The Australian

National University, Canberra, Australia.

doi.org/10.22459/DD.04.2018.29 